$551.573: 551.515 .4$

\title{
Water-substance Budget over the Japan Sea and the Japan Islands during the Period of Heavy Snow Storm
}

\author{
by K. Ninomiya \\ Meteorological Research Institute, Tokyo \\ (Manuscript received 11 June 1964)
}

\begin{abstract}
The winter weather in 1963 was unusually severe over the Far East, and many observation stations in Japan reported new records of the amount of snow fall. This case may be a suitable situation to study about the water-vapor supply from the Japan Sea and the snow fall over the Japan Islands.

Water-substance budget over these areas were analysed using the data of ten days from January 16th to 26 th, during which special observations were carried out under the Heavy Snow Storm Project. It is concluded that the amount of evaporation from the Japan Sea was about $5 \mathrm{~mm} \mathrm{day}{ }^{-1}$, and that the transport of water-substance in the form of liquid or solid water is very important to explain the large amount of snow fall over the Japan Islands. The liquid or solid water content in the active convective cloud over the coastal area of the Japan Sea was estimated, by the budget analysis, to be about $0.4 \mathrm{gr} \mathrm{kg}^{-1}$ (i.e. about $0.4 \mathrm{gr} \mathrm{m}^{-3}$ ). It is also found, that the amount of snow fall over the Japan Islands was especially large in front of a cold vortex.
\end{abstract}

\section{Introduction}

The study of modification of air-mass over the ocean has been performed by many authors. The modification of polar-continental air-mass from the Eurasian Continent is remarkable in winter due to the large air-sea temperature difference. The Japan Sea is surrounded by the Japan Islands, Siberia and the Korea Peninsula, and is enclosed by the radiosonde stations, so that this area is one of the most suitable places for the investigation. Manabe (1957, 1958) found, in his budget analysis over the Japan Sea, that the mean amount of evaporation and sensible heat supplied from the sea surface in winter were about $5.6 \mathrm{~mm} \cdot \mathrm{day}^{-1}$ and $550 \mathrm{ly} \cdot \mathrm{day}^{-1}$ respectively, and that those for the period of typical outburst of cold air appeared remarkably large, i.e. $7.5 \mathrm{~mm} \cdot \mathrm{day}^{-1}$ and $1030 \mathrm{ly}^{\mathrm{day}}{ }^{-1}$ respectively.

The condensation of water-vapor supplied from the Japan Sea is considered to cause the intense snow fall over the Japan Sea side of the Japan Islands. Especially Hokuriku district, where the mean amount of monthly precipitation in January is as much as 300 or $500 \mathrm{~mm}$, is well known as one of the heavist snow fall areas in the world. This phenomenon provides also an interesting problem of the budget analysis. Mastsmoto etal (1963) showed in their analysis of watervapor budget over the Japan Islands that such large amount of snow fall is not explained only by the condensation of watervapor over land because the mixing ratio of water-vapor in winter is small. They suggested that the transport of the water substance in the form of liquid or solid-water would be important to explain the tremendous amount of snow.

On the other hand, as the result of the synoptic analysis of the heavy snow storm, many authors, such as Kawamoto and Miyazawa (1963), and Matsumoto etal (unpublished), pointed out the intimate relation between cold vortex in the troposphere and heavy snow fall over the Japan Islands.

January in 1963 was memorable for the extreme severity of the cold weather over the North America, Europe and the Far East. 
Abnormal coldness hit the Far East accompanied by blizzards, nortably in the northwest coastal area of the Japan Islands, where many observation stations reported new records of hourly, daily and monthly snow fall amount. The special observations including radio-sonde observations at Wajima, Takayama and Niigata were carried out by the Heavy Snow Storm Project for the ten day period of the most severe weather situation from 16th to 26 th January. The water-substance budget over the Japan Sea, the Japan Islands and the small area of the Hokuriku District are analysed during the period mentioned above.

\section{Network of radio-sonde stations and out- line of the analysis}

Since the Japan Sea and the Japan Islands are enclosed by the compartively dense network of radio-sonde stations, it is possible to obtain the comparatively accurate value of the divergence of water-vapor flux. The amount of the precipitation is observed accurately over the Japan Islands and the amount of evaporation from the sea surface, where the water surface temperature is observed, is calculated by using Jacobs formula. Thus, combining these calculations, we can discuss the water substance budget over the area under the consideration.

The network of radio-sonde stations used in the analysis are presented in Fig. 1. The polygonal areas enclosed by the stations are defined in the present paper as "the Japan Sea area", "the Japan Islands area" and "the small area in Hokuriku District". Thus, "the sea area" contains small part of land and "the islands area" contains small part of sea. The dimensins of these areas are shown in Table 1.

The mean vertical cross-sections of the mixing ratio of water-vapor along the coastal lines of the continent and the Japan Islands are presented in Fig. 2 to show the general situation about the water-vapor distribution during the investigated period. Before the passage of the air mass over the Japan Sea, the mixing ratio of water vapor is very small, say, only $0.7 \mathrm{gr} \cdot \mathrm{kg}^{-1}$. During the passage the mixing ratio remarkably increases and the value at sea level over the Japan Sea

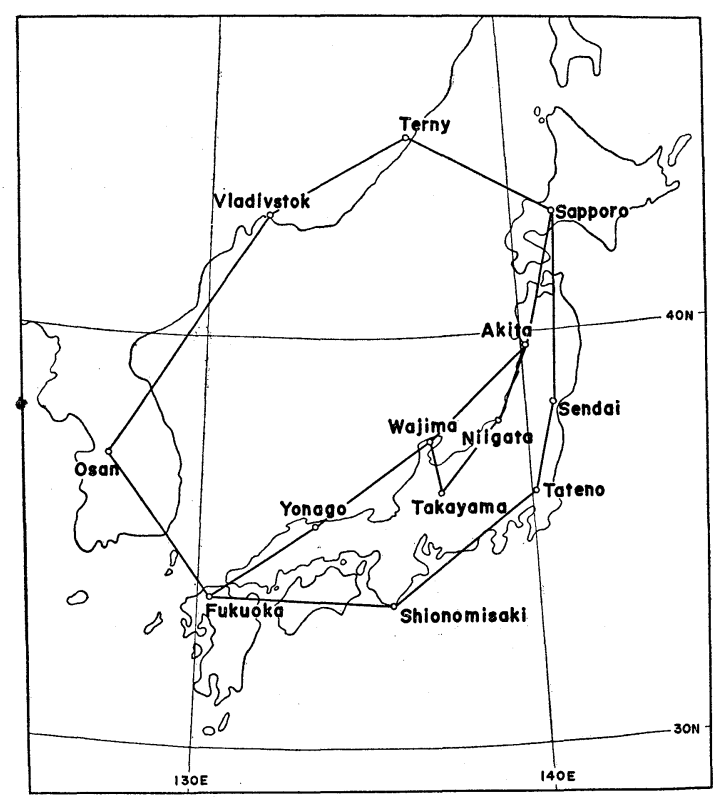

Fig. 1. Network of radio-sonde stations adopted for the present calculations.

Table 1. The dimension of the polygonal areas on which analysis is carried out. (the unit is $10^{8} \mathrm{~m}^{2}$ )

\begin{tabular}{l|r|r|r}
\hline \multicolumn{1}{c|}{ name of the area } & $\begin{array}{c}\text { total } \\
\text { area }\end{array}$ & sea area & $\begin{array}{r}\text { land } \\
\text { area }\end{array}$ \\
\hline the Japan Sea area & 8,244 & 7,263 & 981 \\
the Japan Islands area & 2,773 & 808 & 1,965 \\
$\begin{array}{c}\text { the small area in Ho- } \\
\text { kuriku District }\end{array}$ & 302 & 240 & 62 \\
\hline
\end{tabular}

side of the islands is about $3 \mathrm{gr} \cdot \mathrm{kg}^{-1}$. After the passage of the air mass over the mountains in the islands, low humidity and comparatively higher temperature are observed generally over the Pacific side of the Islands, and the mixing ratio itself is not so small as compared with that of the Japan Sea side.

\section{The equation of water-substance budget}

The equation used for the water-substance budget analysis is

$$
\begin{aligned}
& \frac{1}{g} \int_{p_{1}}^{p_{0}} {\left[\frac{\partial q}{\partial t}+\nabla \cdot q v+\frac{\partial}{\partial p} q \omega+\frac{\partial c}{\partial t}\right.} \\
&\left.+\nabla \cdot c v+\frac{\partial}{\partial p} c \omega\right] d p+r-e=0,
\end{aligned}
$$



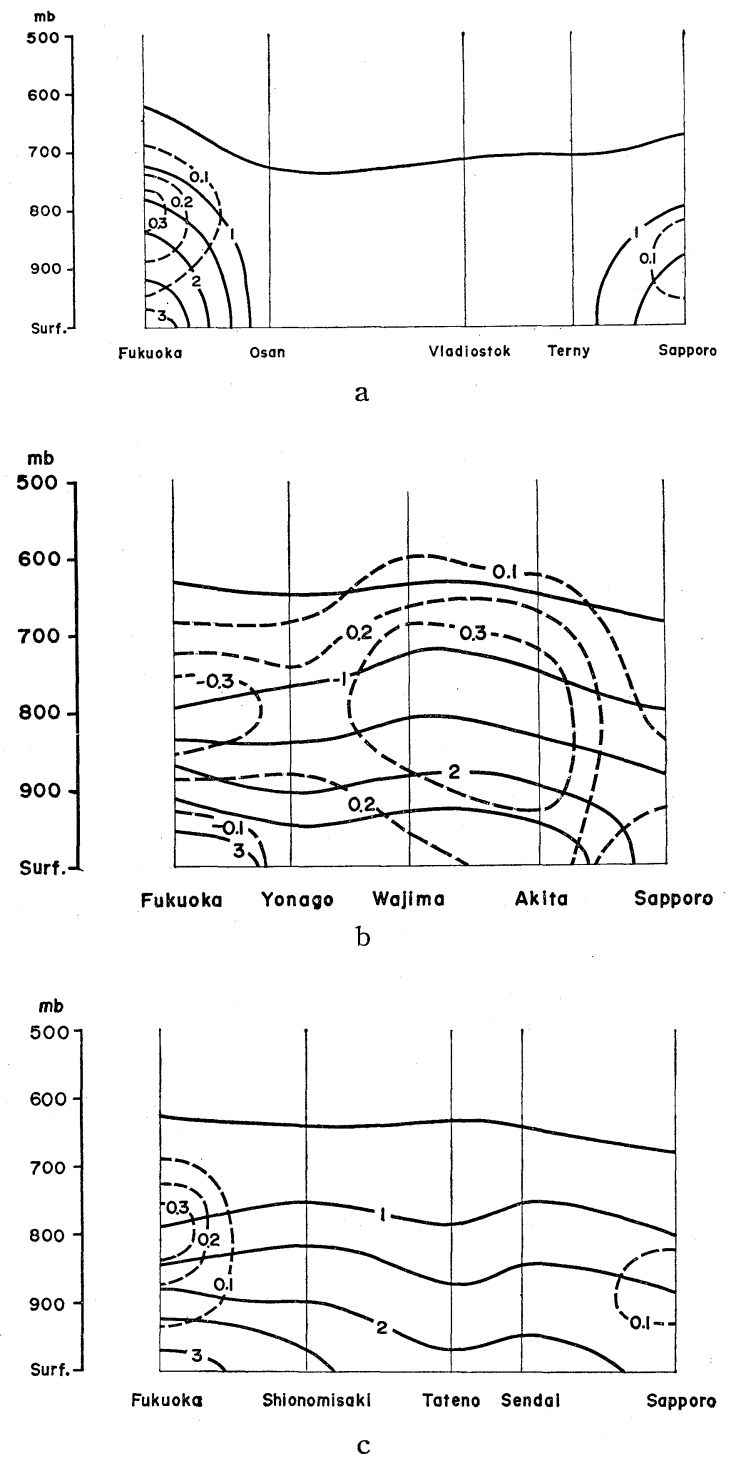

Fig. 2. Mean vertical distribution of mixing ratio of water vapor (solid line) and liquid and solid water (see section 4, broken line) along the coastal line of the continent (a), the Japan Sea side coastal line of the Japan Islands (b) and the Pacific side coastal line (c).

where $p_{0}, q_{0}, c, r$ and $e$ are the pressure at the earth's surface, mixing ratio of water vapor, mixing ratio of water-substance except water vapor (i.e., the mixing ratio of solid and liquid water), the amount of precipitation and the amount of evaporation from the sea or land surface. By using the procedure introduced by Matsumoto etal (1963), eq. (1) is rewritten as follows;

$$
\begin{gathered}
\frac{1}{g}\left[\frac{\partial}{\partial t} \int_{p_{1}}^{p_{0}} q d p+\nabla \cdot \int_{p_{1}}^{p_{0}} q v d p-q_{1} \omega_{1}\right] \\
+\frac{1}{g}\left[\frac{\partial}{\partial t} \int_{p_{1}}^{p_{0}} c d p+\nabla \cdot \int_{p_{1}}^{p_{0}} c \boldsymbol{v} d p-c_{1} \omega_{1}\right] \\
+r-e=0 .
\end{gathered}
$$

The temperature in the middle of troposphere is extremely low during the investigated period, and observation of humidity or dewpoint temperature is extremely scarce above $500 \mathrm{mb}$. The mixing ratio of water vapor at $500 \mathrm{mb}$, however, is estimated to be at most $0.2 \mathrm{gr} \mathrm{kg}^{-1}$. The fact is also observed that the activity of the convective cloud is almost limited in the lower troposphere (Asai, (1964)). Therefore the following assumption is adopted in the eq. (2);

$$
q=c=0 \text { for } p \leq 500 \mathrm{mb} \text {. }
$$

Then eq. (2) is integrated over the investigated area after the third and sixth terms are dropped out with the aid of eq. (3),

$$
\begin{gathered}
\frac{1}{g} \int \frac{\partial}{d t} \int_{p_{1}}^{p_{0}} q \mathrm{~d} p d S+\frac{1}{g} \oint \int_{p_{1}}^{p_{0}} q V_{n} d p d s \\
+\frac{1}{g} \int \frac{\partial}{\partial t} \int_{p_{1}}^{p_{0}} c d p d S+\frac{1}{g} \oint \int_{p_{1}}^{p_{0}} c V_{n} d p d s \\
+\int r d S-\int e d S=0,
\end{gathered}
$$

where $d S, d s$ and $V_{n}$ are the area element, line element of the integral circuit and the wind velocity component normal to the line element $d s$, and $p_{1}$ denotes $500 \mathrm{mb}$.

When the mean budget of water-substance is discussed, eq. (4) is to be averaged over the investigated period (i.e. 10 days). Then the first and the third terms become smaller by two order of magnitude than those of the other terms. Thus eq. (4) is rewritten, to express the mean budget, as

$$
\begin{aligned}
& \bar{F}_{q}+\overline{F_{c}}+\bar{R}-\bar{E}=0, \\
& F_{q}=\frac{1}{g} \oint \int_{p_{1}}^{p_{0}} q V_{n} d p d s, \\
& F_{c}=\frac{1}{g} \oint \int_{p_{1}}^{p_{0}} c V_{n} d p d s, \\
& R=\int r d S \text { and } E=\int e d S,
\end{aligned}
$$


where the bar denotes the time average.

\section{Water-substance budget over the Japan Islands and the Japan Sea}

(1) The mean water-substance budget over the Japan Islands.

To discuss the mean water-substance budget over the Japan Islands, each term in eq.

(5) is evaluated with respect to the polygonal area which is defined as "the Japan Islands area" in the previous section.

The total amount of the precipitation over this area is accurately evaluated by using the network of the surface weather station, including about 90 synoptic weather-stations and also about 1,100 climatological stations. The distribution of the total amount of precipitation during the investigated period of 10 days is shown in Fig. 3. By is definition given in eq. (6), $\bar{R}$ in eq. (5), the mean amount of precipitation, which is calculated to be $838.7 \times 10^{11} \mathrm{gr} \cdot$ hour $^{-1}$.

According to the formula after Jacobs (1951), the amount of the evaporation from the sea surface is computed by the following equation,

$$
m_{J}=0.23 V\left(q_{w}-q_{a}\right),
$$

where $V, q_{w}$ and $q_{a}$ are the surface wind speed in $\mathrm{m} \cdot \mathrm{sec}^{-1}$, saturation mixing ratio of watervapor at the surface sea-water temperature and the mixing ratio at the surface in $\mathrm{gr} \cdot \mathrm{kg}^{-1}$ and $m_{J}$ is in $\mathrm{mm} \cdot \mathrm{day}^{-1}$. As for the coastal sea area included in the considered area, the surface sea-water temperature used in eq (7) are obtainable in Ten-Day Marine Report issued by Japan Meteorological Agency. The obtained amount of evaporation from the sea surface in the area under consideration is $266.1 \times 10^{11} \mathrm{gr} \cdot \mathrm{kg}^{-1}$.

Next, the evaporation from the land surface should be considered. Ito (1957, 1958), comparing experimentally the amount of evaporation from the ground under various conditions with that measured by the evaporation gauge, showed the ratio of the former to the later is about 0.7. Also he evaluated it by the heat budget at the surface layer of the ground under the assumption of the steady state and using the same eddy diffusivity for both sensible heat and watervapor. According to his results, the evaporation in January are very small, especially in the north-eastern part of Japan (for example $15 \mathrm{~mm}$ month $^{-1}$ at Sendai and $4 \mathrm{~mm}$ month ${ }^{-1}$ at Karuizawa). A little larger values are obtained over the same area by Senshu (1959) under the similar assumptions. Considering the results by the authors mentioned above the climatological value observed by evaporation gauge multiplied by the factor of 0.5 is used as the amount of evaporation from the ground in the present study. Thus, the total amount of evaporation in this area is estimated to be $68.0 \times 10^{11} \mathrm{gr} \cdot$ hour $^{-1}$. This treatment is not so highly accurate. Fortu-

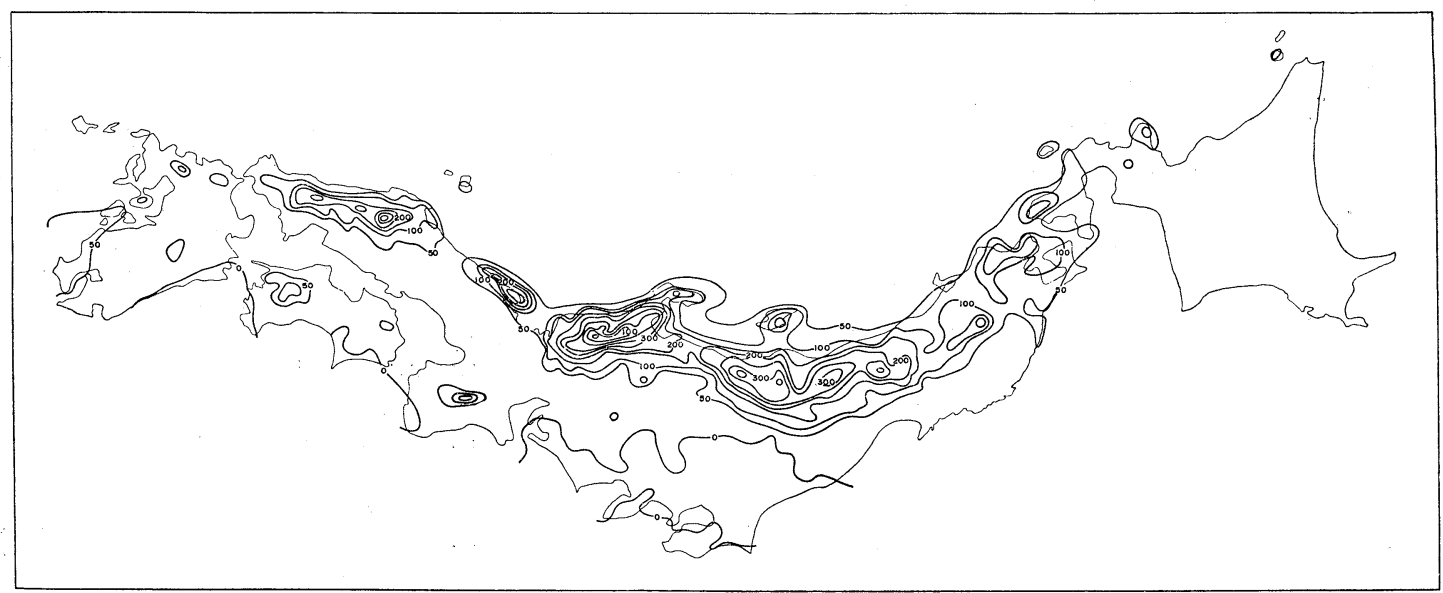

Fig. 3. The distribution of the total amount of the precipitation over the Japan Islands in the investigation period. (unit is $\mathrm{mm}$ ) 
nately, however, the error in this evaluation has little effect on the whole budget analysis, because the amount of evaporation from the ground is smaller by one order of magnitude as compared with other terms in eq. (5).

The term of the divergence of water-vapor flux, i.e. the first term in eq. (5) is calculated, by using the radio-sonde observations according to the defenition given in eq. (6), as $167.0 \times 10^{11} \mathrm{gr} \cdot$ hour $^{-1}$.

The term of divergence of liquid and solid water flux $\bar{F}_{c}$ in eq. (5) is not obtainable by the direct calculation, because there is no observation available on the liquid and solid water content $c$ to be used in eq. (6). Thus, this term is obtained as the residual in eq. (5),

$$
\begin{gathered}
-\bar{F}_{q}-\bar{R}+\bar{E}=\bar{F}_{c} \\
-(-167.0)-838.7+334.3=-337.4,
\end{gathered}
$$

where the unit is $10^{11} \mathrm{gr}^{\circ}$ hour $^{-1}$.

As seen in above equation, the amount of $\overline{F_{c}}$ is about twice large as that of $\overline{F_{q}}$. In other words, it is concluded that the flux of liquid and solid water is very important to explain the large amount of snow fall over the Japan Islands in this heavy snow fall period. Although as the usual situation in winter, higher and lower humidity are observed over the Japan Sea side and the Pacific side of the Japan Islands respectively, the mixing ratio in the Pacific side is not so small, as shown in the previous section, as compared with that over another side. Consequently $i t$ is rather obvious that the convergence of the water-vapor flux is not so large as usually supposed.

(2) Liquid and solid water content in cloud layer

As the convergence of the liquid and solid water flux obtained as the residual in eq. (5) is quite large, it would be necessary to check this value and also to estimate the liquid and solid water content $c$ in the cloud layer by the cloudphysical considerations.

Since liquid and solid water content is not measured by the radiosonde observation, some assumptions are necessary to consider this term. So far as the transport of the water substance is concerned, the layer of cumulonibus, cumulus and nimbostratus are important and the layer of high or middle cloud is to be neglected in the consideration. It is assumed that, at first, the above mentioned clouds exist only in the layer where relative humidity exceeds a critical value, and that, secondary the constant value of liquid and solid water content is contained only in the cloud layer. These assumptions are written as

$$
c(x, y, p, t)=\left\{\begin{array}{lll}
a & \text { for } & h(x, y, p, t) \geq h_{m} \\
0 & \text { for } & h(x, y, p, t)<h_{m}
\end{array}\right.
$$

where $c$ and $h$ are the liquid and solid water content and the relative humidity respectively, $a$ and $h_{m}$ are the constants.

As the following equation is given by eqs. (6) and (8),

$$
\begin{aligned}
& \frac{1}{g} \oint \int_{p_{1}}^{p} c V_{n} d p d s \\
& \quad=-337.4 \times 10^{11} \mathrm{gr} \cdot \text { hour }^{-1},
\end{aligned}
$$

the relation between the unknown constants $a$ and $h_{m}$ in eq. (9) is obtained as shown in Fig. 4.

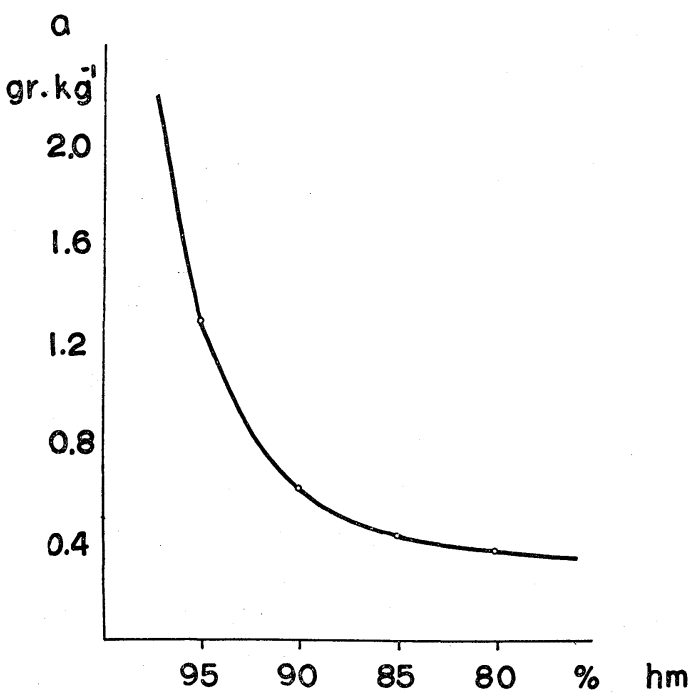

Fig. 4. The relation between $a$ and $h_{m}$, required by eqs. (9) and (10).

On the other hand, the assumptions mentioned above are related with the cloud cover which is observable by the synoptic weather stations. So we add another assumption as follows,

$N_{c}(x, y, t)=\left\{\begin{array}{l}8 \text { for } \max \text { of } h(x, y, p, t) \geq h_{m} \\ 0 \text { for max of } h(x, y, p, t)<h_{m}\end{array}\right.$

Vol. 42, No. 5, 1964 
Nc

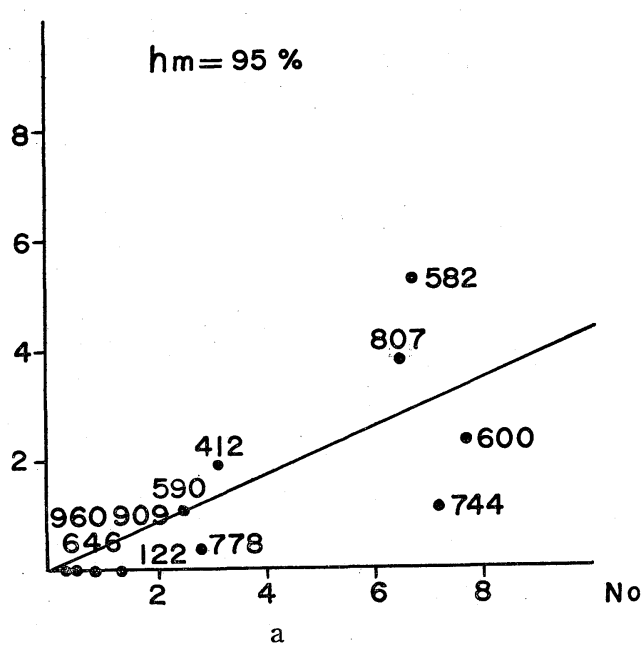

Nc

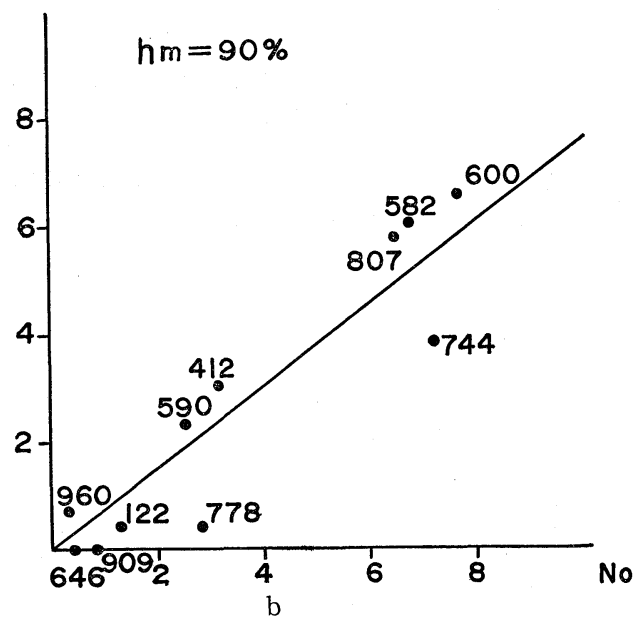

Nc

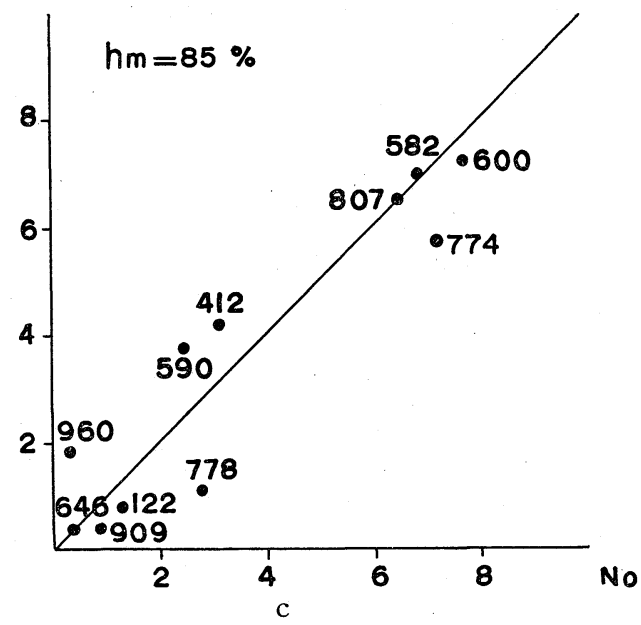

NG

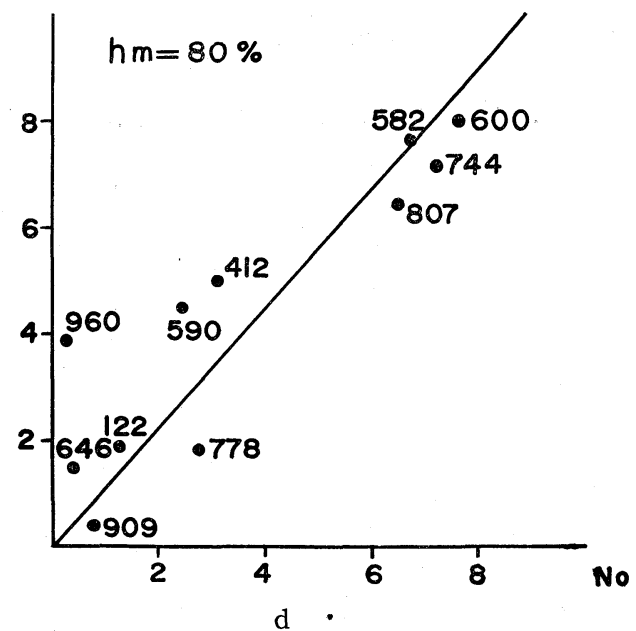

Fig. 5. The relation between the mean calculated cloud cover $N_{c}$ for the various values of $h_{m}$ and the observed mean cloud cover $N_{0}$ at each station. Figures denote the international station numbers.

where $N_{c}$ is the cloud cover. (The octal scale is used as the unit in the present paper). By comparison between the mean calculated and the mean observed cloud cover during the investigated period, the critical value $h_{m}$ in eqs. (10) and (11) is to be decided. The relation between the mean calculated cloud cover obtained by using eq. (11) at each station for the various values of $h_{m}$ and the actually observed mean cloud cover at each station are presented in Fig. 5. When $h_{m}$ is taken as $85 \%$, as seen in Fig. 5, the calculated value almost coincides with the observed one, and the constant $a$ is decided as $0.43 \mathrm{gr} \cdot \mathrm{kg}^{-1}$ for this value of $h_{m}$ as seen in Fig. 4. It is also found in these figures that if $h_{m}$ is taken as higher as 90 or $95 \%$, the cloud cover calculated by eq. (11) is not only underestimated but also the unreasonably large value of liquid and solid water content in cloud layer is required, and that if $h_{m}$ is taken as smaller as $80 \%$, the cloud cover calculated by eq. (11) is overestimated.

Similar relations between cloud distribution and humidity was also shown by the present author (1962). He showed in the synoptic analysis using TIROS cloud photographs that the areas where the dewpoint depression is smaller than $5^{\circ} \mathrm{C}$ are almost overcasted with dense low clouds and cumuli and that the broken or scattered clouds are observed in the areas where the dewpoint depression is 
smaller than $10^{\circ} \mathrm{C}$.

The actual liquid water contents in cumuli were measured by Warner (1955), Squires (1958) and Ackerman (1959) by using aircraft sampler. As the content varies greatly according to other cloud parameters such as temperature or saturated mixing ratio at the cloud base, the "relative water content" defined as the ratio of observed water content to the "adiabatic water content", which is the water content calculated for an air parcel rising moist adiabaticaly from the cloud base without the loss of water, is used for comparison. Although the relative water content calculated for the obtained value of $a\left(=0.43 \mathrm{gr} \cdot \mathrm{kg}^{-1}\right)$ over the Japan Sea coastal area is considerably larger as compared with the values by the authors mentioned above as seen in Fig. 6, this evaluation would be very resonable, because the cumuli investigated by these authors were rather inactive. On the other hand, very active clouds with intense snow fall such as cumulonimbi or cumli congestus are observed over the Japan Sea coastal area for the present case.

As the result of these discussions, it is concluded as to the mean situation during the inverstigated period that the dense cloud which

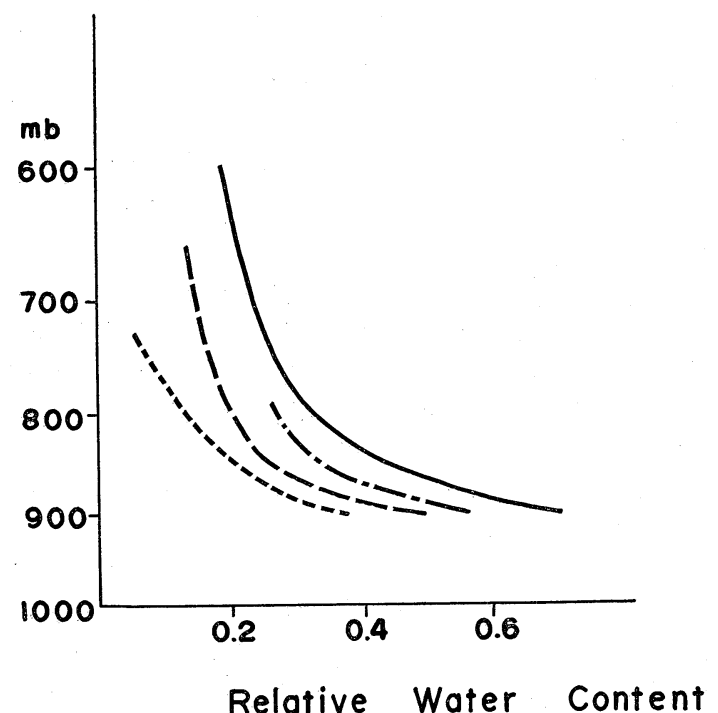

Fig. 6. The comparison between the relative water content estimated by the budget analysis (-) and obtained by Ackerman $(-\cdot-\cdot-)$, Squires (- - ) and Warner $(\cdots \cdots)$. contributes to water substance transport exists in the layer where relative humidity exceeds $85 \%$ and that the mean liquid and solid water content in these layers is about 0.43 $\mathrm{gr} \cdot \mathrm{kg}^{-1}$. The mean distributions of the liquid and solid water content obtained by the previous discussions are presented in Fig. 2 with the mixing ratio of water-vapor.

(3) Water-substance budget over the Japan Sea.

The mean water-substance budget during the ten day period over the Japan Sea area is studied by using eqs. (5) and (6) in this section.

The amount of precipitation over the coastal land areas included in the investigated area is obtaind as $69 \times 10^{11} \mathrm{gr} \cdot$ hour $^{-1}$ by using the network of surface weather stations. As for the evaluation over the sea area, the rough interpolation between the Japan Islands and the Continent is inevitable because of no data of the precipitation over this area. Several observations at the small islands off the coast of the Japan Sea, such as Hekarujima, Sado, Tobishima, Okinoshima, indicate that the most of precipitation is concentrated to coastal area. The estimated distributiun of the amount is presented in Fig. 7, and from it,

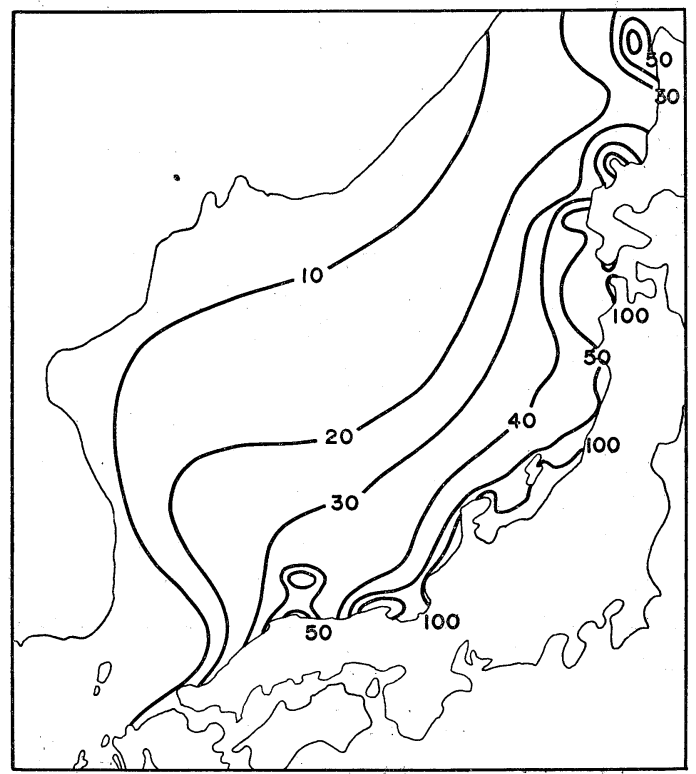

Fig. 7. The distribution of the total amount of precipitation over the Japan Sea in the investigated period (unit is $\mathrm{mm}$ ). 


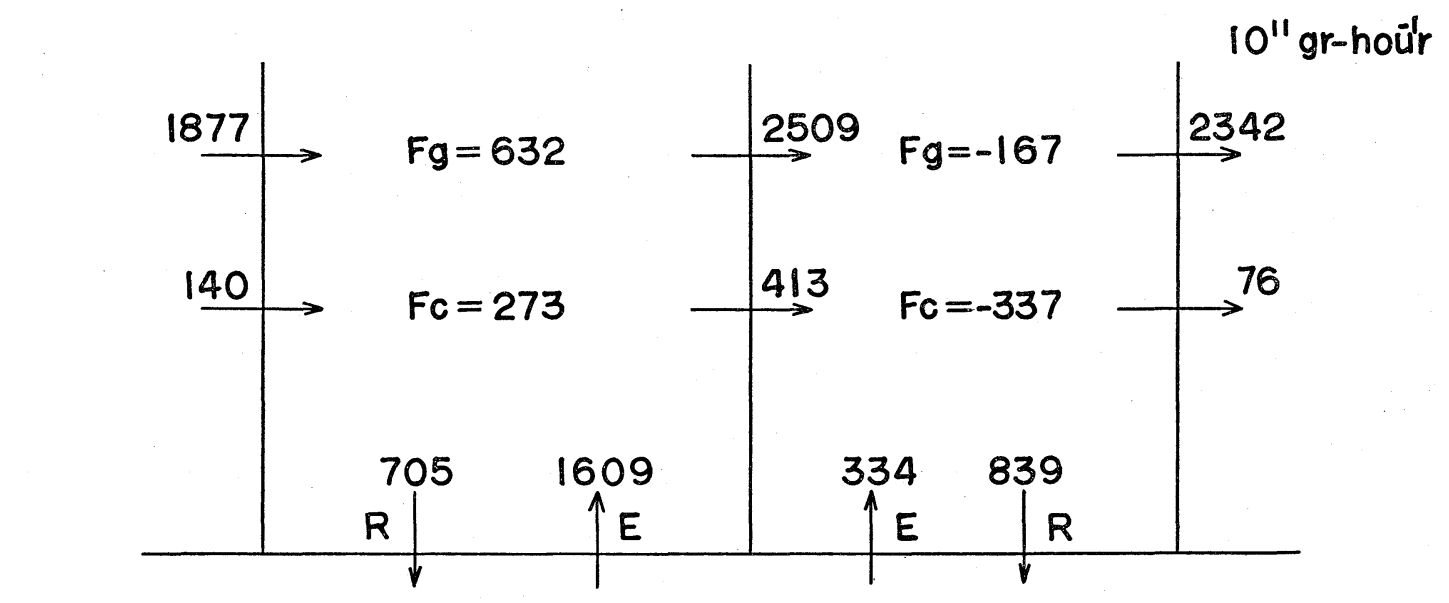

\section{CONTINENT JAPAN SEA}

JAPAN ISLANDS PACIFIC

Fig. 8. The mean water-substance budget over the Japan Sea and the Japan Islands.

the mean amount of precipitation is obtained as $636 \times 10^{\text {i1 }} \mathrm{gr} \cdot$ hour $^{-1}(=2.1 \mathrm{~mm} \cdot$ day $)$.

The divergence of water-vapor flux $\bar{F}_{q}$ is obtained as $632 \times 10^{11} \mathrm{gr} \cdot$ hour $^{-1}$ by using eq. (6) with the radiosonde observation.

As for the liquid and solid water content, the following equation can be used from the discussion in the previous section,

$$
\begin{aligned}
& c(x, y, p, t)= \\
& \begin{cases}0.43 \mathrm{gr} \cdot \mathrm{kg}^{-1} & \text { for } h(x, y, p, t) \geq 85 \% \\
0 & \text { for } h(x, y, p, t)<85 \%,\end{cases}
\end{aligned}
$$

where the notations are used as same as in eq. (11). Thus the divergence of liquid and solid water flux $\bar{F}_{c}$ is calculated, by using eqs. (6) and (12) with the radio-sonde observation, as $273 \times 10^{11} \mathrm{gr}$ hour $^{-1}$.

The amount of evaporation from the ground over the inverstigated area is estimated by the same procedure as used in the previous section. This amount is only $32 \times 10^{11} \mathrm{gr}$. hour $^{-1}$ and negligibly small as compared with other terms.

The evaporation from the Japan Sea surface, where no data to be used in Jacobs formula, $i$. e. eq. (7) is available, is then obtained as the residual in eq. (5),

$$
\begin{gathered}
\overline{F_{g}}+\overline{F_{s}}+\bar{R}-\bar{E}_{L}=\overline{E_{s}} \\
632+273+705-31=1578\left(5.5 \mathrm{~mm} \cdot \mathrm{day}^{-1}\right),
\end{gathered}
$$

where $\bar{E}_{L}$ and $\bar{E}_{s}$ are the total amount of evaporation from the ground and sea surface
Table 2. Evaporation and precipitation over the Japan Sea obtained in this paper and by Manabe (1958). (unit is $\mathrm{mm} \cdot$ day $^{-1}$ )

\begin{tabular}{c|c|c}
\hline & Evap. & Precip. \\
\hline $\begin{array}{c}\text { Period of heavy snow storm } \\
\text { (16-26 Jan. '63) }\end{array}$ & 5.4 & 2.1 \\
$\begin{array}{c}\text { Winter of 1955 } \\
\text { (2 Dec. '54-26 Feb. '55) }\end{array}$ & 5.6 & 2.0 \\
$\begin{array}{c}\text { Period of outburst } \\
\text { (20 Dec. '54-3 Jan. '55) }\end{array}$ & 7.5 & 1.3 \\
\hline
\end{tabular}

respectively, and the unit is $10^{11} \mathrm{gr} \cdot$ hour $^{-1}$. The term of the divergence of liquid and solid water flux is important also in this area, if this term is neglected in eq. (5), the evaporation from the Japan Sea would be considerably underestimated. The accuracy of $\overline{E_{s}}$ evaluated by eq. (13) depends mainly on that of $\bar{R}$. The error of $\overline{E_{s}}$, however, is at most $\pm 1 \mathrm{~mm} \cdot$ day $^{-1}$, even if the relative error of $\bar{R}$ is as much as $50 \%$.

The obtained value of evaporation and precipitation during this period is compard with the result obtained by Manabe $(1957,1958)$ in Table 2. It is notable that the amount of evaporation from the Japan Sea during the period of the extremely intense snow fall over the Japan Islands is almost equal to the value obtainad for the usual winter.

At last the mean water substance budget over both the Japan Sea and the Japan Islands are presented in Table 3 and Fig. 8. Also 


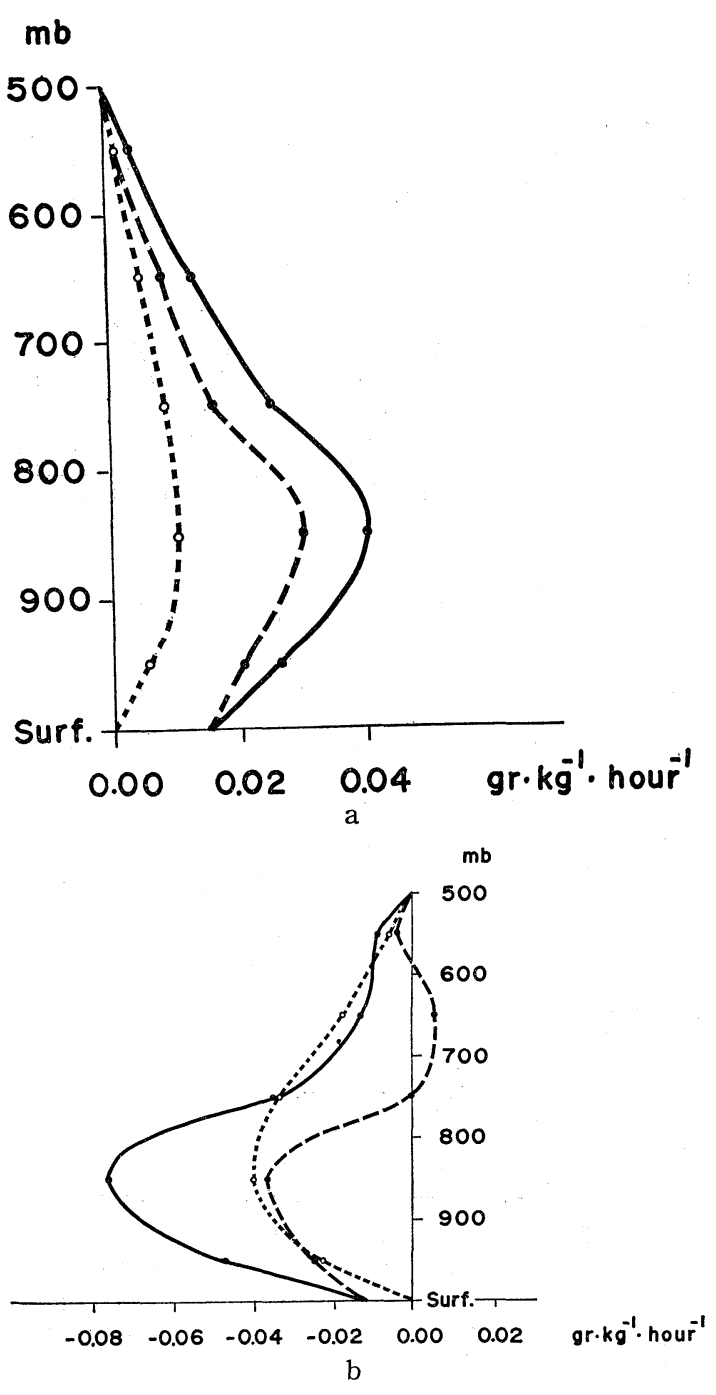

Fig. 9. The vertical distributions of the horizontal divergence of water-vapor flux $\nabla \cdot q \boldsymbol{v}$ (- - ) , that of liquid and solid water flux $\Delta \cdot c \boldsymbol{v}(\cdots \cdots)$ and that of water-substance flux $\nabla \cdot(q+c) \boldsymbol{v}(-)$ over the Japan Sea (a) and the Japan Islands (b).

Table 3. Budget of water substance over the Japan Sea and the Japan Islands area (unit is $10^{11} \mathrm{gr} \cdot \mathrm{hour}$ ).

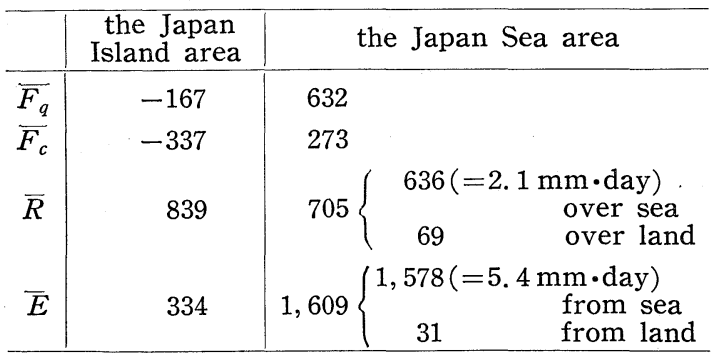

the vertical distribution of the horizontal divergence of water-vapor and liquid and solid water flux over the both areas are presented in Fig. 9. The maxima of these quantities appear at $850 \mathrm{mb}$, and it is negligibly small above $600 \mathrm{mb}$.

\section{Water-substance budget over the small area in Hokuriku district}

Water-substance budget over the small quadrilateral area, formed by four radio-sonde stations, Akita, Wajima, Takayama and Niigata (see Fig. 1), is studied in the present section. This area is located at the coastal part of the Hokuriku district, where the snow fall is extremely intense as seen in Fig. 2.

In this case, all the terms in eq. (5) can be evaluated independently. At first, the total amount of the precipitation over this area is obtained as $120.4 \times 10^{11} \mathrm{gr}$ hour $^{-1}$, or $9.6 \mathrm{~mm} \cdot \mathrm{day}^{-1}$. The total amount of the evaporation is $83.7 \times 10^{11} \mathrm{gr}$ hour $^{-1}$, almost all part of which is supplied from the sea surface and is calculated by using eq. (7) together with the surface observation of sea and water temperature. By using eqs. (5) and radiosonde observation, the amount of divergence of watervapor flux and that of liquid and solid water flux are evaluated as $-42.7 \times 10^{11}$ $\mathrm{gr} \cdot$ hour $^{-1}$ and $14.3 \times 10^{11} \mathrm{gr}$ hour $^{-1}$ respectively. Thus, eq. (5) for this area is written as

$$
\begin{gathered}
\bar{F}_{q}+\bar{F}_{c}+\bar{R}-\bar{E}=0 \\
-42.7+14.3+120.4-83.7 \quad(=8.3)
\end{gathered}
$$

(unit is $10^{11} \mathrm{gr} \cdot$ hour $^{-1}$ ). Although the independently evaluated values of four terms do not strictly satisfy eq. (5), the discrepancy is, as seen in eq. (14), very small as compared with the value of each term, so that the reliability is fairy high.

The vertical distribution of horizomtal divergence of water substance flux over this area is presented in Fig. 10.

As the mixing ratio of water-vapor and the water content over Niigata is almost equal to those over Wajima, the divergence of watersubstance flux is not so much. The large part of the evaporation from the sea surfce and the convergence of water-vapor flux is consumed as the precipitation over this area. 


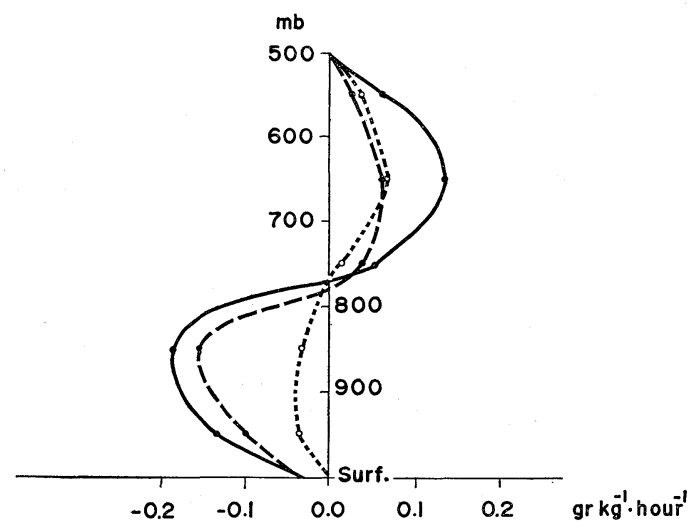

Fig. 10. Same as Fig. 9, but over the small area in Hokuriku District.

However some portion of them is still transported into the inland area of the islands as the form of liquid or solid water, thus positive value of $\bar{F}_{c}$ is observed.

The convergence of water-vapor flux appears, as seen in Fig. 10, in the layer below $800 \mathrm{mb}$, and the divergence of liquid and solid water flux is significant in the layer between $800 \mathrm{mb}$ and $600 \mathrm{mb}$.

\section{The time variation of water-substance budget and its relation to the synoptic weather situation}

In this section the time variation of watersubstance budget is discussed. For this purpose eq. (4), which contains the terms of the time change in the mixing ratio of water-vapor and liquid water, is used.

At first the variation of precipitation over the Japan Islands is discussed. The. first, second, third and fourth terms in eq. (4) are calculated by using 12-hourly radio-sonde observation with the aid of eq. (12). The amount of evaporation from the coastal sea is also obtained 12-houly by using eq. (7). As for the evaporation from the ground, the mean value obtaind in section 4 is used instead of the value calculated 12-hourly, because it is so small to have a reliable estimation of it. Thus as the residual in eq. (4), the amount of 12-hourly precipitation, which is defined here as the calculated precipitation, is obtained. The amount of observed 12-hourly precipitation obtained by the network of synoptic weather stations and the climatological stations is compared with the above

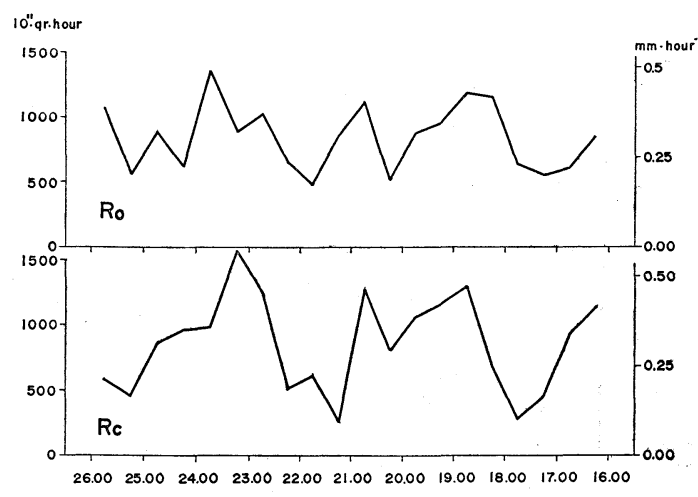

Fig. 11. The time variation of the amount of observed $\left(R_{0}\right)$ and calculated $\left(R_{c}\right)$ precipitation over the Japan Islands.

mentioned calculated one in Fig. 11. The good accordance between them as obviously seen in this figure show the propriety of eq. (12) again. The role of the liquid and solid water, $i$. $e$. the third and fourth terms in eq. (4) is very important also in the water-

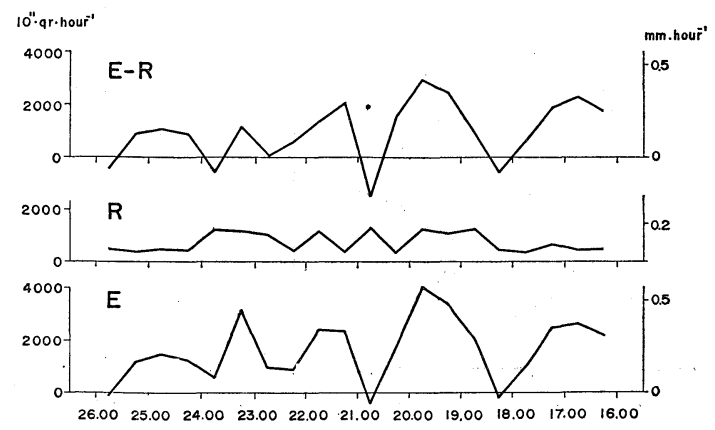

Fig. 12. The time variation of the amount of evaporation $(E)$ from the Japan Sea and that of the precipitation $(R)$ over the Japan Sea.

substance budget in the short time interval.

Next, the time variation of the amount of evaporation from the Japan Sea surface is calculated. In this case, other five terms in eq. (4) are evaluated with 12-hourly observed data, and as the residual the amount of evaporation for 12 hour interval is evaluated (Fig. 12). Negative values of evaporation appear at 18th, 20th and 25th, which would be the result of the error in the evaluation of each term in eq. (4). The maximum evaporation during the investigated period is about $0.5 \mathrm{~mm}$. hour ${ }^{-1}$ and is about 2.5 times as large as the mean value. 
Finally the time variation of the watersubstance budget are briefly discussed in relation to the synoptic weather situation. For the same period as is considered in this paper, the synoptic analysis on the cold vortices, which are extremely predominant in this winter, are investigated by Mastumoto etal. The time section of the mean potential temperature and the static stability over the Japan

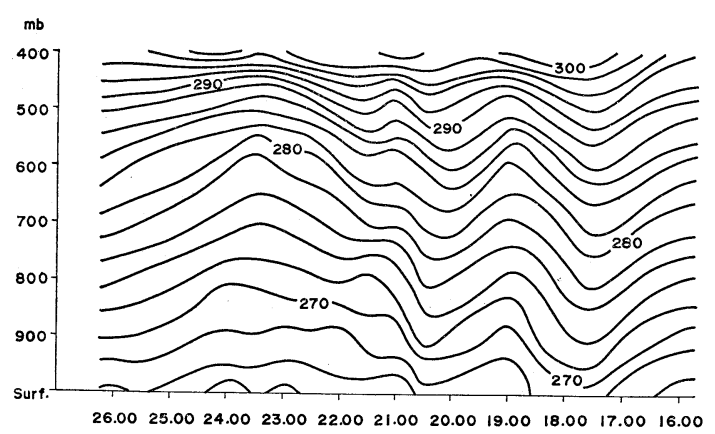

a

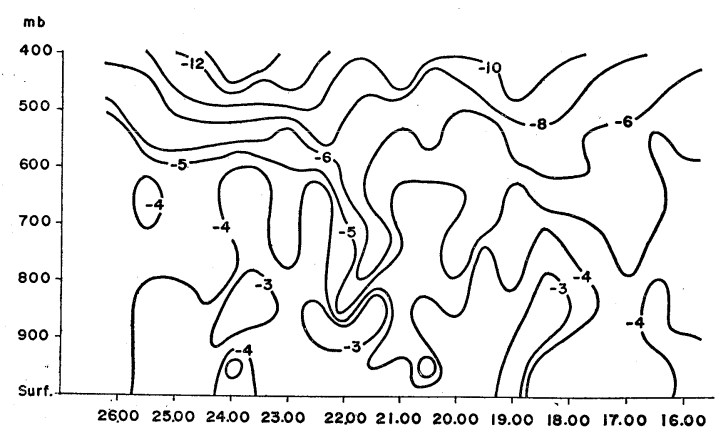

b

Fig. 13. The time variation of the mean potential temperature (a) and that of the mean vertical static stability (in deg./0/100 mb) over the Japan Sea (b).

Sea area are persented in Fig. 13. Three cold vortices passed accross the investigated area duriug the ten day period, $i$. e. at Jan. 19th, 21th and 24th as seen in Fig. 13. Matsumoto pointed out that the thermal axises of these cold vortices are inclined towards their moving direction especially when they move into the Japan Sea. This inclination is seen in the time section of vertical stability, $i . e$. less stable static stabilities are observed in front of the cold vortices.

The intimate relation between the cold vortex in the troposphere and the heavy snow storm over the Japan Islands, as pointed out by several authors mentioned in the first section, is obviously seen in the comparison between the Figs. 11 and 13. However the relation between the 12 hourly amount of the precipitation over the Japan Islands and that of the evaporation from the Japan Sea is rather obscure. The time variation of the sensible heat supply from the Japan Sea is obtained by the present author (1964) in his analysis of heat budget over the Japan Sea and the Japan Islands, and the result is reproduced in Fig. 14. The remarkable max-

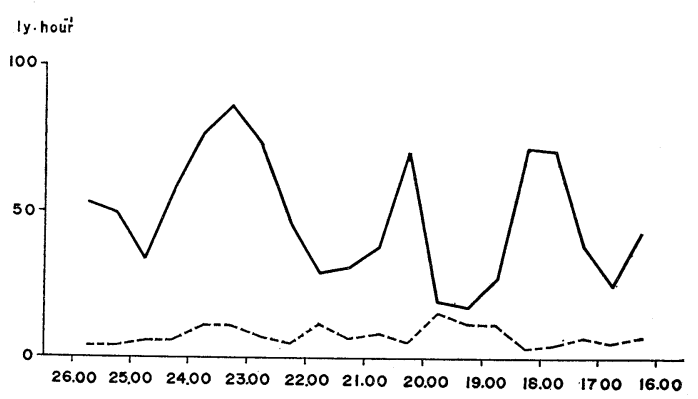

Fig. 14. The time variation of the total heating (solid line) and that of the heating due to condensation and radiation (broken line) over the Japan Sea.

ima of the sensible heat supply appear in front of the cold vortices where maxima of horizontal wind convergences and vertical upward motions are also observed.

Considering the results mentioned above, the relation between the synoptic weather situations and the water-substance budget would be summarized as follows. The sensible heat supply from the Japan Sea increases according to increasing water-air temperature difference when cold vortex approaches the Japan Sea. The temperature of lower layer of the atmosphere does not decreased so much as in higher layer because of the heating from the sea surface, and consequently the vertical static stability decreases. This is a favourable condition for the development of convective motions. The evaporation from the sea surface, however, does not always increase under the above mentioned conditions, because the surface seawater temperature itself decreases to a certain extent following the decrease of air tempera- 
ture, and the saturation mixing ratio of watervapor is very sensitive to the temperature. Even though the evaporation from the sea surface does not increase, the decrease in static stability mentioned above is favourable condition for condensation process through convective motions. Also the large amount of the liquid and solid water, suspended in the cloud layer by strong convective motion, is transported into the Japan Islands and yield effectively large amount of snow fall.

\section{Conclusions}

The results obtained in the forefoing sections are summarized as follows.

(1) The evaporation from the Japan Sea during a period of intense snow fall was $5.4 \mathrm{~mm} \cdot$ day $^{-1}$ which is nearly equal to the normal value.

(2) The considerable portion of the watervapor supplied from the Japan Sea is transported into the Japan Islands in forms of liquid and solid water.

(3) This type of transport of the watersubstance is very important to explain the extremely large amount of snow fall over the Japan Island.

(4) This type of transport seemed to have taken place mainly in the cloud layer where the relative humidity exceeded $85 \%$. The liquid or solid water content in these clouds was estimated, by the budget analysis, to be about $0.4 \mathrm{gr} \cdot \mathrm{kg}^{-1}$.

(5) The enormous amount of snow fall over the Japan Islands was observed in front of a cold vortex. The amount of evaporation from the Japan Sea was not especially large in this period, so that it is inferred that the heavy snow fall may be explained by the high efficiency in condensation process or in transport process through convective motion under the special synoptic situation as mentioned above.

\section{Acknowledgement}

The writer wishes to thank Dr. H. Arakawa for his stimulations and Dr. S. Matsumoto, Mr. A. Katayama and Mr. T. Asai for their helpful discussions and suggestions. The writer is also greatly indebted to Miss. Imai and Miss. Fukazawa for their valuable assistance and Mrs. Tsuneoka for typewriting the manuscript.

\section{References}

Ackerman, B., 1959: The variability the water contents of tropic cumuli. J. Meteor., 16, 191-198.

Asai, T., 1964: Photograhic observation of clouds by aircraft during snowfall period in Hokuriku district. J. meteor. Soc. Japan, 40, 186-196.

Ito, N., 1957: On the evaporation from ground. J. Electric Power and Weather, 8, 183-194.

Jacobs, W.C., 1951: Large-scale aspect of energy transformation over the oceans. Compendium of Meteorology, 1057-1070.

Kawamoto, T. and S. Miyazawa, 1963: The heavy snow fall along the local front over Hokuriku district. Kisho Kenkyu Note, 14, 56-70.

Manabe, S., 1957 : On the modification of air-mass over Japan Sea when the outburst of cold air predominates. J. meteor. Soc. Japan, 35, 311326.

- 1958: On the estimation of energy exchange between the Japan Sea and the atmosphere during winter based upon the energy budget of both the atmosphere and the sea. $J$. meteor. Soc. Japan, 36, 123-135.

Matsumoto, S., T. Asai and K. Ninomiya, 1963: Heat and water-vapor budget in large and small scale in winter over the middle of the Japan Islands. Pap. Meter. Geophys., 14, 67-81.

Ninomiya, K., 1962: Investigation of a summer jet stream using TIROS and aerological data. Res. Pap. No. 14 Meso Met. Project, Univ. of Chicago.

, 1964: Heat budget over the Japan Sea and the Japan Islands during the period of heavy snow storm. (to be published)

Senshu, T., 1959: On the estimation of evapotranspiration from land. J. meteor. Res., 11, 762-771.

Squires, P., 1958: The spatial variation of liquid water and droplet concentration in cumuli. Tellus, 10, 372-380.

Warner, J., 1955: The water content of cumuliform cloud. Tellus, 7, 449-457. 


\title{
豪雨時の日本海・日本列島における水収支解析
}

\author{
二 宮 洸 三 \\ 気像研 究所
}

1963 年 1 月の裏日本の降雪量は記録的な大ささであった。低温のためと混合比の著しく少ない冬期に極めて大き な降水量がみられたと云う点からも，また豪雪の日本海からの水蒸気の補給量との関係と云う観点からあ，この豪 雪は興味深いケースであった。特飞降雪の激しかった 1 月16日から26日にいたる10日間とついて日本列島日本海上 と扮ける水物質の収支解析を行なつて次の結果を得た。

(1) この期間の日本海からの蒸発量は $5.4 \mathrm{~mm} \cdot \mathrm{day}^{-1}$ であって，通常の冬期の蒸発量とほぼ等しいと云う事が できる。

（2）日本海から補給された水蒸気のうち，かなりの部分が海上で㠜結し，液相文は固相の水の形態で日本列島の 上飞輸送されたと推定される。

（3）この液相又は固相の水物質の日本列島上への輸送はこの冬期と招ける様な極めて大量の降雪量の説明に重 要 である。

（4）上記の液・固相の水の輸送飞有効飞働く雲層は相対湿度 $85 \%$ 以上の層飞存在し，その雲層内の液・固相の水 物質の混合比は $0.4 \mathrm{gr} \cdot \mathrm{kg}^{-1}$ の程度である事が推定された。

（5）綜観的な気象状態と比較すると，上層の寒冷渦の前面で降雨量が著しく増大している事が認められた。しか し日本海からの蒸発量はその時必ずしも增加するとは限らない。したがつて上述の降雪量の增加は, 成層の安定度 の減少する寒冷渦の前面で活発化する対流活動とよつて凝結が能率よく行なわれる事飞原因すると思われる。 